\title{
MILLENNIAL GENERATION'S VIEWS ON THE MYTH OF “JILU MARRIAGE” IN NGANJUK EAST JAVA
}

\author{
IMAM BASTHOM I \\ Mahasiswa Sejarah dan Kebudayaan Islam UIN Sunan Kalijaga Yogyakarta JI. Laksda Adisucipto, Papringan, Caturtunggal, \\ Kec. Depok, Kabupaten Sleman, DIY. Email: basthomi04@gmail.com
}

\begin{abstract}
One of Indonesia's attractive cultures is available in the Javanese culture, especially in marriage tradition. Javanese marriage has been practiced in the forms of ritual or traditional ceremonies one of which is Jilu marriage. Jilu marriage is a customary law that prohibits a marriage between the fisrt child and the third child. Javanese people believe that the transgression of this law may bring about misfortune. This study explores how millennial generations view this tradition This research was conducted by using qualitative and quantitative approaches. Methods of collecting data include interview, literature review, and questionnaire. Quantitative data relies upon the statistic method while qualitative data is analyzed by reducing, exposing, and making conclusion. The study found that the mythology of Jilu marriage derives from Javanese ancestors' beliefs that regard number 3 as sacred number. Interestingly, millennials views of this can be categorized into three groups: those who believe, those who do not take it into consideration, and those who are neutral.
\end{abstract}

KEY WORDS: Jilu marriage, myth, Nganjuk, millennial generation.

\section{PANDANGAN GENERASI MILENIAL TERHADAP MITOS PERNIKAHAN “JILU” DI NGANJUK JAWA TIMUR}

\begin{abstract}
Abstrak
Salah satu budaya di Indonesia yang menarik untuk dikaji adalah budaya Jawa. Salah satunya terletak pada bidang pernikahan. Dalam melaksanakan pernikahan ada serangkaian ritual atau upacara adat yang harus dilaksanakan. Salah satu aturannya adalah dilarang melakukan pernikahan Jilu, yakni menikahkan anak nomor satu dengan anak nomor tiga karena dipercaya akan mendatangkan malapetaka. Pada era modern masyarakat Jawa masih ada yang percaya terhadap tradisi tersebut dan ada juga yang sudah meninggalkan. Artikel ini bertujuan untuk memberikan deskripsi tentang mitos pernikahan Jilu dan pendapat generasi milenial tentang mitos tersebut. Penelitian ini menggunakan pendekatan kualitatif dan kuantitatif. Metode pengumpulan data menggunakan wawancara, studi pustaka, dan kuesioner. Data kuantitatif yang ada dianalis dan disajikan dengan model statistika (diagram batang dan lingkaran) dan dilakukan penarikan kesimpulan, sedangkan data kualitatif dianalisis dengan cara mereduksi serta memaparkan data, dan penarikan kesimpulan. Hasil penelitian ini menunjukkan mitos pernikahan Jilu berasal dari kepercayaan nenek moyang suku Jawa yang mengkeramatkan angka 3 dan dampaknya sering terjadi karena menjadi guneman masyarakat. Generasi milenial di Nganjuk ada yang percaya dengan tradisi Jilu, ada yang tidak percaya, dan ada yang bersikap netral.
\end{abstract}

KATA KUNCI: pernikahan Jilu, mitos, Nganjuk, generasi milenial

* Naskah diterima Agustus 2020, direvisi September 2020, dan disetujui untuk diterbitkan November 2020 


\section{A. Pendahuluan}

Indonesia merupakan negara kepulauan terbesar di dunia yang terdiri dari pulau-pulau dengan lebih dari 300 kelompok etnik yang menghuninya. Berdasarkan data sensus Badan Pusat Statistik (BPS) pada tahun 2010 jumlah etnik atau suku bangsa di Indonesia mencapai angka 1.340. Suku Jawa menjadi kelompok terbesar di Indonesia dengan jumlah $41 \%$ dari total jumlah populasi penduduk. ${ }^{1}$ Masyarakat Jawa terkenal memiliki tradisi budaya yang beragam. Tradisitradisi tersebut melekat dalam berbagai pola kehidupan masyarakatnya. Pranata-pranata yang ada bahkan menjadi sebuah kearifan budaya lokal tersendiri. Kearifan budaya lokal ialah pengetahuan lokal yang sudah menyatu dengan sistem kepercayaan, norma, dan budaya, serta diekspresikan dalam tradisi dan mitos yang dianut dalam jangka waktu yang lama. Kearifan lokal merupakan sesuatu yang berkaitan secara spesifik dengan budaya tertentu (budaya lokal) dan mencerminkan cara hidup suatu masyarakat tertentu (masyarakat lokal). ${ }^{2}$

Kearifan budaya lokal yang dimiliki masyarakat Jawa bahkan menjadi sebuah hukum adat. Menurut Hardjito Notopuro hukum adat adalah hukum yang tak tertulis, sebuah hukum kebiasaan dengan ciri khas yang menjadi pedoman kehidupan masyarakat dalam menyelenggarakan tata keadilan dan kesejahteraan masyarakat dan bersifat kekeluargaan. ${ }^{3}$ Dalam ilmu antropologi, kajian topik ini termasuk dalam bidang folklor. Folklor adalah bagian dari kebudayaan kolektif, tersebar dan diwariskan secara turun-temurun. Secara tradisional penyampaiannya bisa secara lisan yang terkadang diiringi dengan gerak isyarat atau dengan alat bantu pengingat (mnemonic device). ${ }^{4}$ Menurut Jan Harold Brunvand folklor ada tiga tipe : ${ }^{5}$ 1) Folklor lisan. 2) Folkor sebagian lisan dan 3) Folklor bukan lisan. Folklor lisan adalah folklor yang bentuknya murni lisan, seperti bahasa rakyat, puisi rakyat, nyanyian rakyat. Folklor

\footnotetext{
${ }^{1}$ https://Indonesia.go.id/profil/suku-bangsa diakses pada 14 Maret 2020

${ }^{2}$ Agung Setiyawan, "Budaya Lokal Dalam Perspektif Agama: Legitimasi Hukum Adat ('urf) Dalam Islam", dalam Jurnal Esensia Vol. 8 No. 2, 2012, hlm. 207.

${ }^{3}$ Dewi Wulansari, Hukum Adat Indonesia-Suatu Pengantar (Bandung: PT Refika Aditama,2010), hlm. 4.

${ }^{4}$ James Danandjaja, Folklor Indonesia (Jakarta: Pustaka Utama Grafiti, 1997), hlm. 2.

${ }^{5} \mathrm{Ibid}$. hlm. 21-22
}

sebagian lisan merupakan folklor yang bentuknya perpaduan unsur lisan dan bukan lisan, seperti kepercayaan rakyat dan permainan rakyat. Folklor bukan lisan adalah folklor yang bentuknya bukan sebuah lisan walau cara proses pembuatannya dilakukan secara lisan, contohnya arsitektur rumah rakyat, makanan-minuman, dan obat-obat tradisional.

Menurut Wayland D. Hand, kepercayaan rakyat atau biasa disebut takhayul dalam lingkup kehidupan manusia ada beberapa yang menjadi latar belakang terjadinya upacara-upacara lingkungan hidup (upacara adat). Di Indonesia menurutnya yang sering nampak pada bidang kelahiran (masa bayi atau kanak-kanak), pernikahan (cinta, jodoh), dan kematian (adat pemakaman). ${ }^{6}$ Pada bidang pernikahan, masyarakat Jawa mempunyai tradisi yang harus dilaksanakan. Beberapa tradisinya ada yang berupa larangan atau pantangan dalam pernikahan. Pantangan atau larangan tersebut muncul bukan karena sebuah kebetulan, melainkan karena adanya faktor-faktor tertentu. Faktor-faktor tersebut dibagi menjadi 3 macam, yakni faktor biologis, faktor sosial, dan faktor alam. Faktor biologis adalah pernikahan yang masih ada hubungan biologis (hubungan pertalian saudara), faktor sosial adalah pernikahan yang jika tetap dilakukan maka akan mendapat gunjingan dari masyarakat, sedangkan faktor alam adalah pantangan pernikahan karena ada sebab rahasia alam atau kekuatan sang pencipta. $^{7}$

Salah satu contoh larangan pernikahan karena faktor alam adalah larangan pernikahan "Jilu". Tradisi tersebut melarang adanya pernikahan anak mbarep/kapisan (pertama) dengan anak ketelu (ketiga), baik dari pihak calon suami maupun istri. ${ }^{8}$ Masyarakat Jawa umumnya mempercayai bahwa pelanggaran terhadap tradisi ini akan berdampak pada ketidakharmonisan saat berkeluarga dan akan menimbulkan sebuah malapetaka berupa musibah bahkan kematian

\footnotetext{
${ }^{6}$ James Danandjaja, Folklor Indonesia (Jakarta: Pustaka Utama Grafiti, 1997), hlm. 155-156

${ }^{7}$ Wahyu Widodo, Makna larangan Pernikahan Adat Jawa di Kecamatan Sooko Kabupaten Ponorogo (perspektif Tujuan Pernikahan dalam Islam), dalam skripsi Fakultas Syari'ah IAI Ponorogo, 2018, hlm. 44-49.

${ }^{8}$ Ayu Laili Amelia, "Larangan Perkawinan Jilu dan Pembinaan Keluarga Sakinah di Kabupaten Blitar", dalam Jurnal De Jure Vol. 10 No. 1, 2018, hlm. 33.
} 
terhadap salah satu orang tua pasangan. Dewasa ini, pendapat masyarakat modern mengenai mitos pernikahan Jilu ini sangat beragam, ada pihak yang sudah meninggalkan dan tidak mempercayai, ada pihak yang tetap mempercayai, ada pihak yang tidak percaya tapi tetap menghormati, dan ada pihak yang masih ragu antara percaya dan tidak.

Berdasarkan uraian-uraian di atas, maka tulisan ini akan menggali lebih jauh tentang mitos larangan pernikahan Jilu yang berada di Nganjuk Jawa Timur. Penulis lebih berfokuskan kepada pandangan generasi milenial terhadap adanya mitos pernikahan Jilu. Apakah generasi milenial termasuk pihak yang mempercayai? Ataukah generasi milenial termasuk pihak yang tidak percaya dan meninggalkan? Ataukah generasi milenial punya pendapat atau argumen tersendiri? Generasi milenial menjadi objek kajian penelitian karena pada generasi tersebut banyak anak yang kurang tahu dan peduli terhadap warisan budaya dan tradisi yang ada di Indonesia. Bahkan mereka mempunyai pandangan tersendiri dalam menyikapi suatu tradisi. Artikel ini berupaya memberikan deskripsi tentang pandangan generasi milenial terhadap mitos pernikahan Jilu.

\section{B. Metode Penelitian}

Penelitian ini dilakukan di Nganjuk Jawa Timur pada bulan April 2020. Jenis penelitian ini adalah penelitian empiris (field research) untuk mendeskripsikan pandangan generasi milenial terhadap fenomena mitos pernikahan Jilu. Pendekatan penelitian menggunakan gabungan pendekatan kualitatif dengan kuantitatif. Dalam pengumpulan data, peneliti melakukan wawancara, studi pustaka, dan survei. Peneliti melakukan wawancara dengan masyarakat di Nganjuk yang paham dengan mitos Jilu dengan menggunakan model wawancara bebas terpimpin dan dengan teknik selected informan. Peneliti mencari karya-karya ilmiah yang berkaitan dengan mitos-mitos Jilu dan pernikahan adat Jawa. Peneliti juga melakukan survei kuesioner menggunakan fitur Google Forms dan disebarkan ke pemuda-pemudi generasi milenial secara acak di daerah Nganjuk Jawa Timur.

Analisis data dilakukan dengan cara mengumpulkan seluruh data wawancara dan studi pustaka. Setelah itu mereduksi data tersebut untuk diklasifikasikan dan dipilih data yang memberikan informasi tentang mitos pernikahan Jilu. Data hasil survei kuesioner dikumpulkan dan disusun dalam bentuk diagram batang dan diagram lingkaran sehingga tergambar apa yang diteliti. Setelah seluruh data sudah lengkap dan memadai, langkah terakhir adalah pengambilan kesimpulan.

\section{Hasil dan Pembahasan \\ Pernikahan Adat Jawa Sebagai Kearifan Budaya Lokal Indonesia}

Kebudayaan dan manusia merupakan hal yang tidak bisa dipisahkan. Suatu kebudayaan dapat lahir dan berkembang karena ada manusia yang mau membentuk dan melestarikannya. Indonesia sebagai salah satu negara dengan kepadatan penduduk yang tertinggi di dunia memiliki keanekaragaman budaya yang melimpah. Setiap daerahnya mempunyai budaya masing-masing dengan karakteristik yang berbeda-beda. Bagi masyarakat Indonesia, tradisi atau budaya memiliki kedudukan yang ditinggikan. Hal tersebut terjadi karena budaya atau tradisi mengajarkan banyak hal. Melalui budaya, manusia akan semakin arif dan bijak dalam menjalani kehidupan karena budaya juga mengandung arti kehidupan yang mendalam tentang kecintaan masyarakat terhadap Tuhan, lingkungan, dan hubungan sesama manusia. ${ }^{9}$ Budaya-budaya yang ada di Indonesia mengandung makna kearifan lokal bagi masyarakat di wilayah asal budaya itu dikenal.

Budaya Jawa memiliki nilai-nilai kearifan lokal yang menyangkut berbagai aspek kehidupan, seperti nilai kepemimpinan, toleransi, nasionalisme, keadilan, kebenaran, kejujuran, kesempurnaan, dan sebagainya. ${ }^{10}$ Salah satu nilai kearifan lokal budaya Jawa yang dapat kita lihat adalah dari upacara atau ritual adat yang masih dilestarikan. Salah satunya adalah tradisi dalam upacara pernikahan. Istilah pernikahan berasal dari bahasa Arab ( أنكا ), para ulama fikih

${ }^{9}$ Lopiana Margaretha Panjaitan dan Dadang Sundawa, "Pelestarian Nilai-Nilai Civic Culture dalam Memperkuat Identitas budaya Masyarakat: Makna Simbolik Ulos dalam Pelaksanaan Perkawinan Masyarakat batak toba di Sitorang", dalam Jurnal Society's Art's Vol. 3 No. 2, 2016, hlm. 65.

${ }_{10}$ Darmoko, "Budaya Jawa Dalam Diaspora: Tinjauan Masyarakat Jawa di Suriname", dalam Jurnal Ikadbudi Vol. 5 No.1, 2016, hlm. 5. 
memberikan definisi pernikahan sebagai sebuah akad yang membawa kebolehan bagi seorang lakilaki untuk berhubungan badan dengan seorang perempuan dengan diawali akad lafal nikah atau makna serupa dengan itu. ${ }^{11}$ Pada masalah pernikahan, masyarakat Jawa umumnya menggunakan tata cara agama Islam dan ritualritual adat yang berlaku. Sebelum melakukan sebuah pernikahan, sebagian masyarakat Jawa melakukan tradisi nontoni, tangeran, dan gethak dina. ${ }^{12}$ Sedangkan pada saat resepsi ada tradisi pasang tarub, serah-serahan, siraman pengantin, kembar mayang, malam midadareni, upacara Panggih, dan upacara ngindak tigan. ${ }^{13}$ Hal-hal tersebut sudah diatur dalam hukum adat pernikahan yang mereka percayai, yakni seperangkat aturan-aturan hukum adat yang mengatur tentang bentukbentuk pernikahan, tata-cara pelamaran, upacara penikahan, dan putusnya pernikahan. ${ }^{14}$

Hukum adat dalam pernikahan adat Jawa memiliki simbol dan nilai-nilai filosifis yang tinggi. Hal itu karena diajarkan oleh nenek moyang secara turun-temurun dengan maksud mengajarkan petunjuk yang baik serta bermanfaat bagi kehidupan manusia yang dalam konteks pernikahan agar terciptanya keluarga yang sakinah. ${ }^{15}$ Dalam realitasnya, banyak masyarakat Jawa menempatkan tradisi sejajar dengan agama atau bahkan menjadi bagian pokok dari agama itu sendiri. Fenomena-fenomena gagalnya suatu pernikahan karena terbentur dengan hukum adat terkadang juga menjadi sebuah dinamika masyarakat Jawa sekarang ini. Salah satunya adalah adanya larangan melakukan pernikahan "Jilu". Pernikahan Jilu dihindari oleh masyarakat Jawa karena diyakini akan membawa sebuah bencana dan malapetaka bagi keluarga tersebut.

\section{Pernikahan Jilu}

Agama Islam mengajarkan dalam memilih

${ }^{11}$ Wahyu Wibisana, "Pernikahan Dalam Islam", dalam Jurnal Ta'lim Vol. 14 No. 2, 2016, hlm. 186.

${ }^{12}$ Romli, Eka Sakti Habibullah, "Telaah Resepsi Pernikahan Adat Jawa Dalam Perspektif Hukum Islam" dalam Jurnal AlMashlah vol.6 No, 2, 2018, hlm. 185-186

${ }^{13}$ Ambarwati, Alda Putri, Indah Lyls Mustika, "Pernikahan Adat Jawa Sebagai Kekuatan Budaya Indonesia", dalam Prosiding Senasbasa, 2018, hlm 19-20.

${ }^{14}$ Romli, Eka Sakti Habibullah, "Telaah Resepsi Pernikahan Adat Jawa Dalam Perspektif Hukum Islam" dalam Jurnal $\mathrm{Al}$ Mashlah vol.6 No, 2, 2018, hlm. 183

${ }^{15}$ Ambarwati, Alda Putri, Indah Lyls Mustika, "Pernikahan Adat Jawa Sebagai Kekuatan Budaya Indonesia", dalam Prosiding Senasbasa, 2018, hlm 18. calon pasangan setidaknya mengacu pada empat hal, yaitu: harta, fisik, nasab (keturunan), dan agama. Faktor-faktor tersebut diharapkan mampu menciptakan keluarga yang sakinah. Pemilihan calon pasangan juga ada pada hukum adat Jawa. Orang Jawa dalam memilih calon pasangan hidup harus mempertimbangkan bibit, bobot, bebet. Tiga faktor tersebut memiliki makna sebagai berikut: Bibit dimaknai sebagai faktor keturunan dari calon mempelai, bebet dimaknai sebagai derajat sosial calon mempelai dan keluarganya dalam masyarakat sedangkan bobot berarti penguasaan terhadap harta benda. ${ }^{16}$ Masyarakat Jawa juga memperhatikan petung (perhitungan) dan larangan-larangan dalam pernikahan adat. Salah satu tradisi larangan yang masih dilakukan dan dipercayai oleh masyarakat Jawa hingga sekarang ini adalah larangan pernikahan Jilu.

Jilu merupakan singkatan dari bahasa Jawa yakni siji dan telu. Siji berarti satu, telu berarti tiga. Maknanya adalah anak nomor satu tidak boleh menikah dengan anak nomor tiga dengan tidak memandang yang nomor satu harus laki-laki atau perempuan, begitu juga sebaliknya. ${ }^{17}$ Misalnya Anton menikah dengan Lisa, Anton anak nomor satu sedangkan Lisa anak nomor tiga atau sebaliknya, maka pernikahan tersebut dinamakan pernikahan Jilu. Adanya tradisi ini menyebabkan banyak orang gagal dalam menikahkan anaknya karena takut apabila melanggar nanti akan berdampak buruk ketika menjalani kehidupan rumah tangga. Masyarakat Jawa yang masih memegang teguh tradisi dan hukum adat Jawa (kejawen) meyakini bahwa pernikahan Jilu memberikan dampak pertengkaran pada pasangan, kehidupan rumah tangga selalu diselimuti berbagai masalah, perekonomian menjadi sulit, dan kematian akan menimpa salah satu pasangan atau keluarga. ${ }^{18}$

Dampak dari pernikahan Jilu tidak bisa dipastikan, terkadang terjadi cepat setelah melakukan akad pernikahan dan terkadang

\footnotetext{
${ }^{16}$ Ayu Laili Amelia, "Larangan Perkawinan Jilu dan Pembinaan Keluarga Sakinah di Blitar", dalam Jurnal De Jure Vol. 10 No.1, 2018, hlm. 34.

${ }^{17}$ Ginting Kurnia Putra Wali Hakim Karena Adat Jilu (Studi Kasus Desa Wonoasri Kecamatan Wonoasri Kabupaten Madiun, dalam skripsi Fakultas Syari'ah IAIN Ponorogo, 2018, hlm. 49

${ }^{18}$ Fendi Bintang Mustopa, Sheila fakhria, "Tinjauan Hukum Islam Terhadap Larangan Pernikahan Adat Jawa Jilu Studi Kasus di Desa Tanggan Kecamatan Gesi Kabupaten Sragen", dalam Jurnal Legitima Vol. 2 No.1, 2019, hlm. 49-50.
} 
setelah memiliki anak. Kasus yang terjadi di masyarakat biasanya ada keluarga yang tidak percaya terhadap larangan pernikahan Jilu dan tetap melanjutkan pernikahan, akhirnya setelah mereka mempunyai anak, orang tua dari salah satu mempelai meninggal, ada juga yang menikah belum lama langsung bercerai. Ada juga kasus orang tua yang tidak mengizinkan anaknya menikah karena berbenturan adat Jilu, akhirnya sang anak minta dinikahkan oleh seseorang yang tidak mempercayai adat tersebut. Beberapa hari setelah menikahkan, orang tersebut langsung meninggal. Tradisi Jilu memang di luar nalar dan akal manusia karena secara ilmiah tidak dapat dibuktikan dan dalam Islam juga tidak ada dalil Al-Qur'an atau hadis yang menjelaskan tentang tradisi Jilu. Pada zaman modern sekarang ini beberapa orang Jawa sudah tidak menggunakan tradisi Jilu. Mereka menganggap tradisi Jilu hanya sebuah mitos dari nenek moyang pada zaman dahulu yang sekarang sudah mulai luntur dan tidak semua pasangan Jilu yang mengalami musibah seperti yang telah berkembang di masyarakat sekitar.

Menurut Bapak Purwanto, seorang seniman dan ahli kebudayaan Jawa, asal usul Jilu sudah ada sejak zaman dahulu. Menurutnya pernikahan Jilu lebih baik dihindari karena anak nomor satu dan anak nomor tiga itu sejatinya akan mengalami banyak cobaan dan ujian, jadi jika disatukan akan bahaya. ${ }^{19}$ Sedangkan menurut Bapak Yusro, seorang pemerhati adat istiadat Jawa, segala hal yang berkaitan dengan adat Jawa adalah suatu perkara yang bersifat sirri (tersembunyi atau rahasia), jadi tidak semua orang mengetahui dan dapat dijelaskan secara gamblang. ${ }^{20}$ Larangan pernikahan Jilu terjadi karena leluhur orang Jawa mengkeramatkan angka "3" karena angka tersebut dihubungkan dengan kejadian-kejadian yang sakral sehingga hal-hal yang berhubungan dengan itu dihindari. Pengkeramatan angka 3 itu diawali dari sebuah kisah seseorang yang mencari keberadaan Tuhan akan tetapi tidak berhasil. ${ }^{21}$ Akhirnya datang hewan yang wujudnya belalang yang tertawa sambil berbicara "kamu itu rajin

\footnotetext{
${ }^{19}$ Wawancara dengan Bapak Purwanto pada 11 Mei 2020

${ }^{20}$ Wawancara dengan Bapak Yusro pada 13 Mei 2020

${ }^{21}$ Fendi Bintang Mustopa, Sheila fakhria, "Tinjauan Hukum Islam Terhadap Larangan Pernikahan Adat Jawa Jilu Studi Kasus di Desa Tanggan Kecamatan Gesi Kabupaten Sragen", dalam Jurnal Legitima Vol. 2 No.1, 2019, hlm. 46.
}

salat, rajin puasa tapi sampai sekarang tidak menemukan rumahnya tuhan. Rumah Tuhan itu ada di tiga tempat: 1 . Perempuan yang ada di rumah suami nya, 2. Di rumah kedua orang tua, 3 Di hati". ${ }^{22}$ Perkara tiga ini sangat berat sehingga menjadi tradisi pengkeramatan perkara angka tiga. Perkara angka tiga dipercaya dapat menimbulkan petaka dan masyarakat enggan dengan hal itu. Akhirnya perkara tiga tersebut juga menjadi asal muasal adanya mitos pernikahan Jilu di masyarakat Jawa. ${ }^{23}$

Berdasarkan hasil wawancara dengan Bapak Purwanto dan Bapak Yusro, dampak tradisi Jilu benar-benar terjadi karena adanya faktor asumsi masyarakat terhadap tradisi tersebut dan asumsi itu telah tersugestikan ke benak masyarakat Jawa. ${ }^{24}$ Mitos Jilu yang menjadi guneman (bahan pembicaraan) masyarakat dan akhirnya menjadi kenyataan. Hal tersebut juga selaras dengan ajaran umat Islam yang menyatakan setiap perkataan merupakan sebuah doa. Menurut Bapak Purwanto jika benar-benar terpaksa melakukan pernikahan Jilu, maka sebaiknya proses atau rangkaian acara pernikahannya dilakukan di tempat lain di mana tidak ada orang yang menggunakan dan mempercayai adat Jilu. ${ }^{25}$

Sedangkan menurut Bapak Yusro jika memang perkara Jilu itu memberikan kemudaratan lebih baik ditinggalkan (sebisa mungkin dihindari) karena sebagai muslim yang tinggal di pulau Jawa sudah seharusnya menghargai adat-adat yang berlaku. Ia menambahkan faktor terpenting dalam pernikahan adalah adanya rida dari kedua orang tua. ${ }^{26}$ Jika memang terpaksa melakukan pernikahan Jilu di daerah yang masih ada masyarakat yang mempercayainya, maka hendaknya pelaku pernikahan Jilu berpegang teguh pada ajaran agama dan sering melakukan puasa serta orang lain jangan sampai tahu jika pernikahan tersebut melanggar adat Jilu. ${ }^{27}$

\section{Mitos Pernikahan Jilu Menurut Para Milenial di Nganjuk Jawa Timur}

Nganjuk merupakan salah satu kabupaten

\footnotetext{
22 Ibid.

${ }^{23}$ Ibid.

${ }^{24}$ Wawancara dengan Bapak Purwanto pada 11 Mei 2020; Wawancara dengan Bapak Yusro pada 13 Mei 2020

${ }^{25}$ Wawancara dengan Bapak Purwanto pada 11 Mei 2020.

${ }^{26}$ Wawancara dengan Bapak Yusro pada 13 Mei 2020.

${ }^{27}$ Ibid
} 
yang ada di Provinsi Jawa Timur. Kabupaten tersebut berbatasan dengan Bojonegoro di sebelah utara, Jombang di sebelah timur, Kediri dan Ponorogo di sebelah selatan serta Madiun di sebelah barat. ${ }^{28}$ Nganjuk yang dikenal sebagai kota angin ini masih memiliki masyarakat yang menjaga tradisi-tradisi nenek moyang. Masyarakat Nganjuk masih menjaga budaya, kesenian, dan tradisi-tradisinya. Peneliti melakukan penelitan tentang bagaimana pandangan generasi milenial Nganjuk terhadap adanya mitos larangan pernikahan Jilu.

Istilah kaum milenial sudah bukan lagi menjadi hal asing di telinga kita. Banyak orang di Indonesia menggunakan istilah tersebut dalam berbagai pembicaraan, kajian ilmu, diskusi dan kegiatan-kegiatan lainnya. Para peneliti dan pakar ilmu di seluruh dunia berbeda-beda dalam memberikan definisi tentang generasi milenial akan tetapi secara umum dapat disimpulkan bahwa generasi milenial adalah mereka yang dilahirkan antara tahun 1980-2000. ${ }^{29}$ Mereka adalah generasi yang melek dengan teknologi dan memiliki pemikiran yang open minded, kritis, berani, dan dinamis (ingin serba cepat). Selain itu kaum milenial juga senantiasa memiliki jiwa produktif, kreatif, inovatif, dan efisien. Ketika Indonesia mengalami bonus demografi nanti generasi milenial inilah yang akan mendominasi berbagai sektor di Indonesia.

Peneliti menggunakan model statistik deskriptif dalam mengolah dan menganalisis data informasi dari survei kuesioner. Statistik deskriptif berfungsi untuk memberikan deskripsi terhadap objek yang diteliti melalui data sampel atau melalui populasi sebagaimana adanya tanpa melakukan analisis dan membuat kesimpulan yang berlaku umum. ${ }^{30}$ Diagram batang dan diagram lingkaran digunakan peneliti untuk menyajikan data-data analisis penelitian. Sedangkan teknik pengambilan sampel menggunakan teknik Sampling Quota. Teknik tersebut merupakan teknik untuk menentukan sampel dari populasi yang mempunyai ciri-ciri

\footnotetext{
${ }^{28}$ https://nganjukkab.bps.go.id/statictable/2016/03/30/32/letakgeografis-kabupaten-nganjuk.html diakses pada 20 Mei 2020.

${ }^{29}$ Indah Budiati dkk, Statistik Gender Tematik: Profil Generasi Milenial Indonesia (Kementerian Pemberdayaan Perempuan dan Anak ,2018), hlm. 14-17.

30 Sugiyono, Statistika Untuk Penelitian (Bandung: Alfabeta,2012), hlm. 29.
}

tertentu sampai jumlah atau kuota yang diinginkan. ${ }^{31}$

Teknik Sampling Quota tidak memperhitungkan jumlah populasi, akan tetapi mengklasifikasikan populasi ke dalam beberapa kelompok dan memberikan jatah atau kuota sampel. setelah jatah tersebut terpenuhi, maka pengumpulan data dihentikan. Dalam penelitian ini kelompok tersebut diklasifikasikan menjadi 3, yakni: rentang usia 15-20, rentang usia 21-25, dan rentang usia 26-30. Jumlah kuota sampel ditentukan sebanyak 50 orang responden tercepat yang mengisi kuesioner. Peneliti menggunakan teknik tersebut karena jumlah dan persebaran populasi generasi milenial di Nganjuk belum diketahui.

Peneliti menggunakan media Google Forms dalam menyebarkan kuesioner. Dari 50 sampel yang telah mengisi Google Form dapat diketahui rinciannya sebagai berikut:
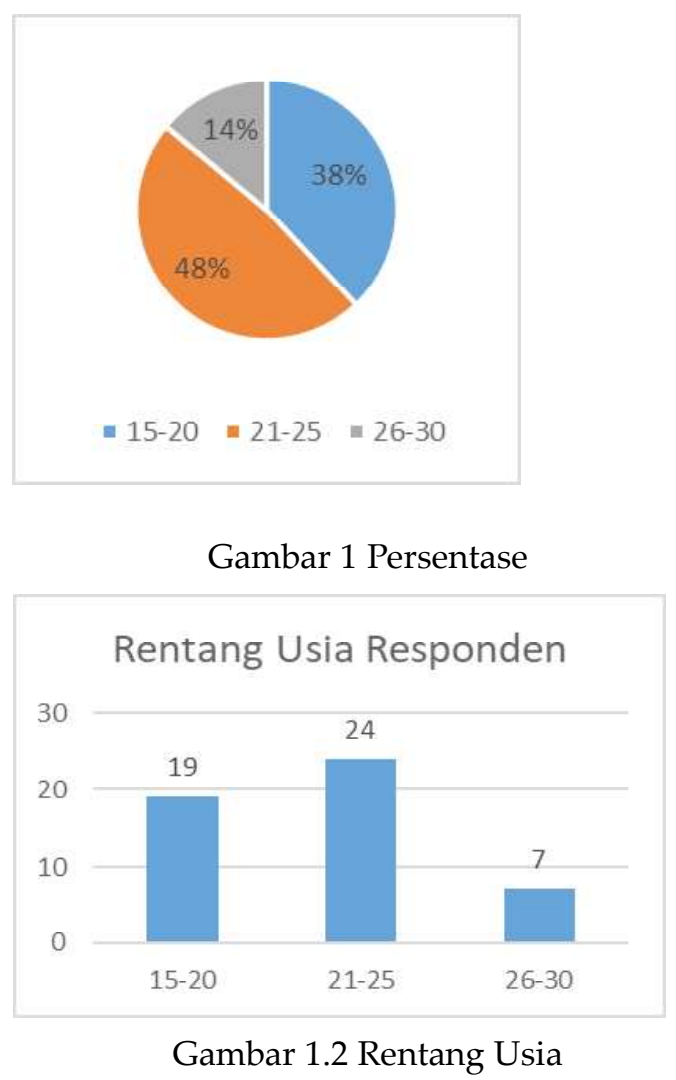

Dari gambar di atas dapat kita ketahui jumlah responden pada rentang usia $15-20$ ada 19 anak (38\%), rentang usia $21-25$ ada 24 anak (48\%), dan rentang usia 26-30 ada 7 anak (14\%). Data ini

\footnotetext{
${ }^{31} \mathrm{Ibid}$, hlm. 67
} 
menunjukkan bahwa mayoritas responden berada di usia antara 21-25. Pada usia tersebut umumnya berstatus sebagai pelajar (mahasiswa) dan pekerja atau pegawai muda. Selanjutnya dalam Google Forms, peneliti memberikan pertanyaanpertanyan terkait tradisi Jilu. Pertanyaan pertama mengenai apakah responden mengetahui terhadap mitos Jilu? Pertanyaan kedua tentang apakah responden mempercayai mitos Jilu? Dan pertanyaan terakhir adalah apakah di daerah sekitar responden masih menerapkan tradisi Jilu? Dan terakhir harus mengisikan komentar atau pendapatnya tentang tradisi Jilu.

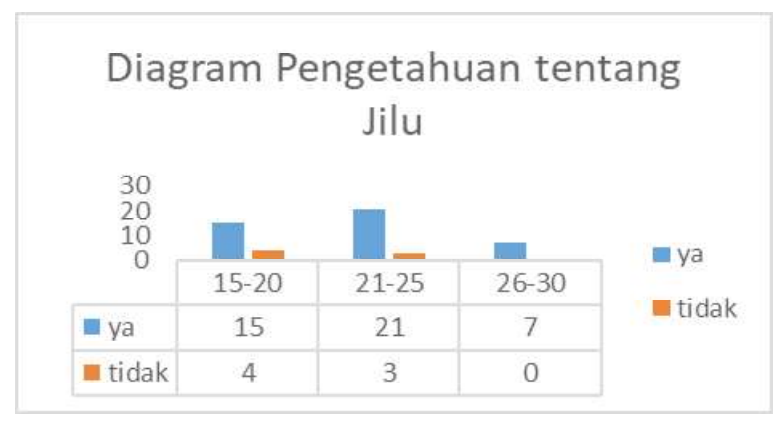

Gambar 2 Pengetahuan Jilu

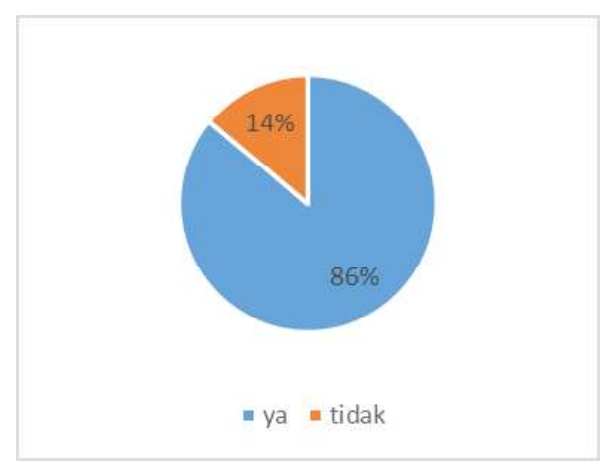

Gambar 2.1 Persentase

Berdasarkan gambar 2.1, 86 \% generasi milenial yang berada di Nganjuk Jawa Timur mengetahui tentang tradisi larangan Jilu. Dari 50 responden hanya 7 anak yang tidak mengetahui. Pada rentang usia 15-20 yang berjumlah 19 responden ada 4 anak yang tidak mengetahui. Pada rentang usia 21-25 yang berjumlah 24 responden ada 3 anak yang tidak mengetahui, sedangkan pada rentang usia 26-30 semua responden mengetahui tentang tradisi Jilu. Dari gambar 2 dan gambar 2.1 dapat kita simpulkan bahwa mayoritas generasi milenial di Nganjuk sekarang mengetahui tentang mitos tradisi Jilu dan semakin muda usianya mulai menunjukkan angka penurunan pengetahuan tentang tradisi Jilu.

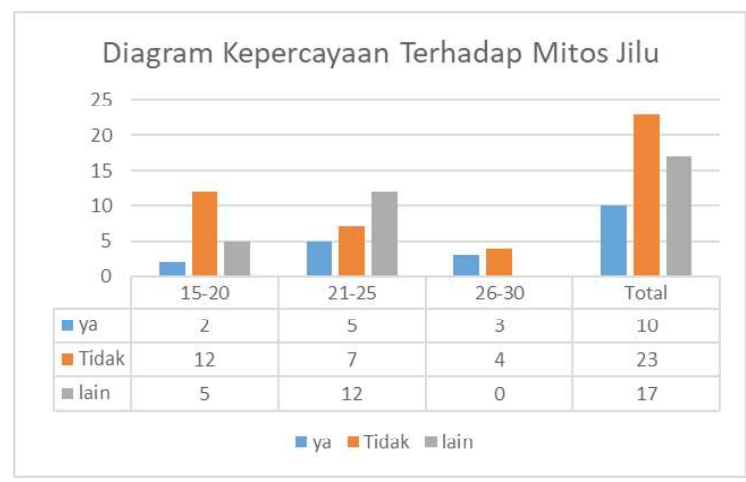

Gambar 3 Diagram Kepercayaan

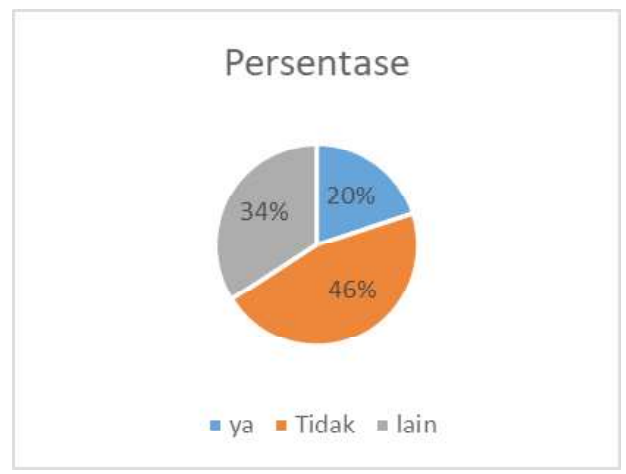

Gambar 3.1 Persentase Kepercayaan

Pada gambar 3 dan gambar 3.1 menunjukkan tentang data statistik kepercayaan terhadap tradisi Jilu. Generasi milenial di Nganjuk 20\% masih mempercayai tradisi Jilu, $46 \%$ sudah tidak mempercayai, dan 34\% lain-lain. Lain-lain yang dimaksud adalah jawaban selain percaya dan tidak. Mereka ada yang ragu, bersifat netral, dan masih binggung antara harus mempercayai atau tidak. Semakin muda usia generasi milenial di Nganjuk, semakin banyak yang tidak percaya dengan mitos Jilu. Jadi dapat kita simpulkan hanya sebagian kecil dari generasi milenial di Nganjuk yang masih percaya dengan mitos pernikahan Jilu.

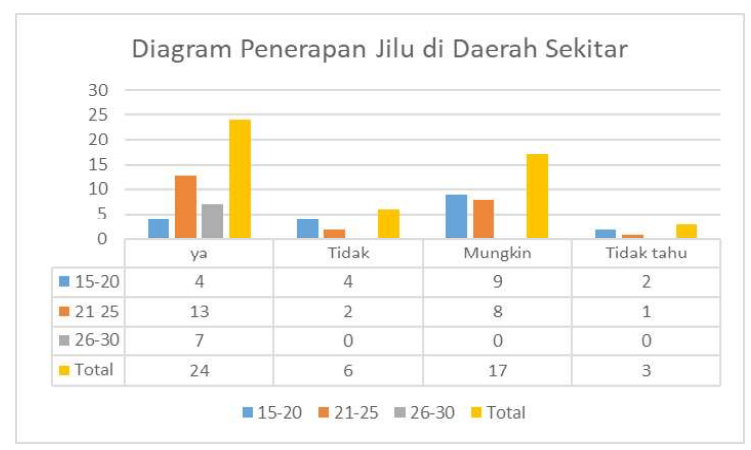


Gambar 4 Diagram Jilu di daerah

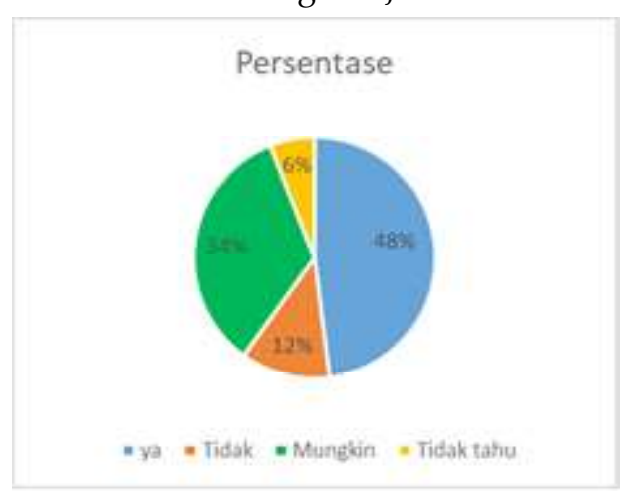

Gambar 4.1 Persentase Jilu di daerah

Gambar di atas menunjukkan persentase "ya" sebanyak $48 \%$ dan persentase "mungkin" sebanyak $34 \%$, hal tersebut dapat kita simpulkan bahwa masyarakat di daerah Nganjuk masih banyak yang mempercayai dan menerapkan tradisi pernikahan Jilu. Menurut generasi milenial Nganjuk masih sedikit masyarakat (orang tua) yang meninggalkan atau tidak mempercayai mitos tradisi Jilu di daerah sekitar mereka.

Berdasarkan data-data dari semua diagram di atas serta hasil telaah komentar individu setiap responden dapat kita simpulkan bahwa pandangan generasi milenial terhadap tradisi Jilu sebagai berikut:

1. Tidak percaya dan mengganggap hanya mitos, dianggap syirik atau dosa besar jika percaya.

2. Tidak percaya tapi masih menghormati dan menghargai setiap tradisi adat Jilu.

3. Percaya dan menerapkan tradisi Jilu.

4. Netral (antara percaya dan tidak percaya).

5. Banyak masyarakat (orang tua) di Nganjuk yang masih percaya terhadap tradisi Jilu.

\section{Kesimpulan}

Masyarakat Jawa mempunyai tradisi-tradisi yang banyak dalam setiap lini kehidupan. Tradisi tersebut memiliki nilai-nilai kearifan lokal. Salah satunya pada bidang pernikahan. Pada pernikahan adat Jawa banyak sekali ditemukan ritual atau upacara adat. Hal tersebut sudah diatur dalam hukum adat yang memiliki simbol-simbol dan nilai filosofis yang tinggi.

Jilu adalah mitos larangan di Jawa yang tidak memperbolehkan melakukan pernikahan anak nomer satu dengan anak nomor 3 karena dipercaya akan mendatangkan musibah dan malapetaka. Musibah yang dimaksud adalah rumah tangganya nanti akan dilanda masalah, perekonomian sulit, dan salah satu pasangan atau mertua akan meninggal. Mitos ini dipercaya masyarakat karena adanya perbedaan sifat antara anak nomer satu dan anak nomor 3 dan adanya pensakralan atau pengkeramatan angka 3 pada masyarakat Jawa. Meski berupa mitos atau pitutur nenek moyang, dampak dari Jilu benar-benar terjadi karena sering menjadi guneman (bahan pembicaraan) masyarakat.

Generasi milenial adalah generasi yang lahir pada tahun antara 1980-2000. Generasi ini merupakan generasi yang akan memenuhi segala sektor di Indonesia ketika bonus demografi terjadi. Para kaum milenial mayoritas mengetahui tentang tradisi pernikahan Jilu. Mereka ada yang percaya, ada yang tidak percaya, dan ada yang netral.

\section{UCAPAN TERIMAKasiH}

Pertama saya ucapkan terima kasih kepada kedua orang tua yang telah memberikan dukungan serta motivasi untuk melakukan penelitian ini. Kedua, saya ucapkan terima kasih kepada Bapak Purwanto dan Bapak Yusro yang telah bersedia menjadi narasumber. Ketiga, saya ucapkan terima kasih kepada para responden yang telah mengisi kuesioner. 
Admin. (n.d.-a). Badan Pusat Statistik Kabupaten Nganjuk. Retrieved March 14, 2020, from https://nganjukkab.bps.go.id/statictable/ 2016/03/30/32/letak-geografis-kabupatennganjuk.html

Admin. (n.d.-b). Indonesia.go.id. Retrieved March 14, 2020, from https://Indonesia.go.id/profil/ suku-bangsa

Ambarwati, Anindika, A. P., \& Mustika, I. L. (2018). Pernikahan Adat Jawa Sebagai Salah Satu Kekuatan Budaya Indonesia. In Prosiding SENASBASA (Vol. 3).

Amelia, A. L. (2018). Larangan Perkawinan Jilu dan Pembinaan Keluarga Sakinah di Kabupaten Blitar. Journal de Jure, 10(1), 31. https://doi.org/10.18860/j-fsh.v10i1.6571

Budiati, I., Susianto, Y., Adi, W. P., Ayuni, S., Reagan, H. A., Larasaty, P., Setiyawati, N., Pratiwi, A. I., \& Saputri, V. G. (2018). Profil Generasi Milenial Indonesia. Kementerian Pemberdayaan Perempuan dan Perlindungan Anak.

Danandjaja, J. (1997). Folklor Indonesia. Jakarta: Pustaka Utama.

Darmoko. (2016). Budaya Jawa Dalam Diaspora: Tinjauan Masyarakat Jawa di Suriname. Ikadbudi, 5(1), 1-19. https://doi.org/https:// doi.org/10.21831/ikadbudi.v5i12

Mustopa, F. B., \& Fakhria, S. (2019). Tinjauan Hukum Islam Terhadap Larangan Pernikahan Adat Jawa Jilu Studi Kasus di Desa Tanggan Kecamatan Gesi Kabupaten Sragen. Legitima, 2(1), 18-39.

Panjaitan, L. M., \& Sundawa, D. (2016). Pelestarian Nilai-Nilai Civic Culture dalam Memperkuat Identitas Budaya Masyarakat: Makna Simbolik Ulos dalam Pelaksanaan Perkawinan Masyarakat Batak Toba di Sitorang. Journal of Urban Society's Arts, 3(2), 64-72. https://doi.org/10.24821/ jousa.v3i2.1481

Putra, G. kurnia. (2018). Wali hakim karena adat jilu (studi kasus di desa wonoasri kecamatan wonoasri kabupaten madiun). http://
etheses.iainponorogo.ac.id/2595/1/Ginting Kurnia Putra.pdf

Romli, R., \& Habibullah, E. S. (2018). Telaah Resepsi Pernikahan Adat Jawa Dalam Perspektif Hukum Islam. Al-Mashlahah: Jurnal Hukum Islam Dan Pranata Sosial, 6(02), 177. https://doi.org/10.30868/am.v6i2.306

Setiyawan, A. (2012). BUDAYA LOKAL DALAM PERSPEKTIF AGAMA: Legitimasi Hukum Adat ('Urf) Dalam Islam. ESENSIA: Jurnal Ilmu-Ilmu Ushuluddin, 13(2), 203. https:// doi.org/10.14421/esensia.v13i2.738

Sugiyono. (2012). Statistika untuk Penelitian. Bandung:Alfabeta.

Wibisana, W. (2016). Pernikahan dalam Islam. Jurnal Pendidikan Agama Islam - Ta'lim, 14(2), 190.

Widodo, W. (2018). Makna larangan pernikahan adat jawa di kecamatan sooko kabupaten ponorogo (perspektif tujuan pernikahan dalam islam). http://etheses.iainponorogo.ac.id/2741/1/ Wahyu Widodo.pdf

Wulansari, D. (2010). Hukum Adat Suatu Pengantar. Bandung: Refika Aditama. 
234 Pandangan Generasi Milenial Terhadap Mitos ... 
